\title{
Corrigendum: Self-reported sleep disturbances in patients with dissociative identity disorder and post-traumatic stress disorder and how they relate to cognitive failures and fantasy proneness
}

\section{Dalena van Heugten - van der Kloet ${ }^{1}{ }^{*}$, Rafaele Huntjens ${ }^{2}$, Timo Giesbrecht ${ }^{1}$ and Harald Merckelbach ${ }^{1}$}

${ }^{1}$ Faculty of Psychology and Neuroscience, Maastricht University, Maastricht, Netherlands

${ }^{2}$ Department of Clinical Psychology, University of Groningen, Groningen, Netherlands

*Correspondence: dalena.vanheugten@ndcn.ox.ac.uk

Edited and reviewed by:

Ruth Benca, University of Wisconsin School of Medicine and Public Health, USA

Keywords: dissociative symptoms, sleep quality, unusual sleep experiences, cognitive failures, fantasy proneness

\section{A corrigendum on}

Self-reported sleep disturbances in patients with dissociative identity disorder and post-traumatic stress disorder and how they relate to cognitive failures and fantasy proneness

by van Heugten - van der Kloet D, Huntjens R, Giesbrecht $T$ and Merckelbach $H$. Front Psychiatry (2014) 5:19. doi:10.3389/ fpsyt.2014.00019

\section{CORRIGENDUM}

Page 2, Material and Methods, paragraph 1

This should read

“(..) 27 female PTSD patients who reported childhood sexual and/or physical abuse (mean age: 40 years, $S D=12.9$ ), and (...) Education was assessed on a scale from
1 (low) to 7 (high) (1). The DID group had a mean of $5.25(\mathrm{SD}=1.48)$ years of education, the PTSD group had studied for a mean of 5.04 years $(\mathrm{SD}=0.90)$, and the controls had finished a mean of 5.82 years of education $(\mathrm{SD}=0.98)$."

Page 2, Results, paragraph 1, third sentence This should read $F(2,93)=5.64, p<0.001$

Table 3, DID group model 4, $R^{2}$

This should read $R^{2}=0.18$

\section{REFERENCE}

1. Verhage F. Intelligentie en leeftijd: Onderzoek bij nederlanders van twaalf tot zevenenzeventig jaar [Intelligence and age: Study with Dutch people from age 12 to 77]. Assen: Van Gorcum (1964).

Conflict of Interest Statement: The authors declare that the research was conducted in the absence of any commercial or financial relationships that could be construed as a potential conflict of interest.

Received: 09 July 2014; accepted: 12 August 2014; published online: 01 September 2014.

Citation: van Heugten - van der Kloet D, Huntjens $R$, Giesbrecht $T$ and Merckelbach $H$ (2014) Corrigendum: Self-reported sleep disturbances in patients with dissociative identity disorder and post-traumatic stress disorder and how they relate to cognitive failures and fantasy proneness. Front. Psychiatry 5:112. doi 10.3389/fpsyt.2014.00112

This article was submitted to Sleep Disorders, a section of the journal Frontiers in Psychiatry.

Copyright () 2014 van Heugten - van der Kloet, Huntjens, Giesbrecht and Merckelbach. This is an open-access article distributed under the terms of the Creative Commons Attribution License (CC BY). The use, distribution or reproduction in other forums is permitted, provided the original author(s) or licensor are credited and that the original publication in this journal is cited, in accordance with accepted academic practice. No use, distribution or reproduction is permitted which does not comply with these terms. 